\title{
The Claim of Human Rights Violations Against China in Covid-19 Case of The Opportunity To Use International Court of Human Rights Mechanisms
}

\author{
Levina Yustitianingtyas ${ }^{1}$, Anang Dony Irawan ${ }^{2}$ \\ ${ }^{1,2}$ University of Muhammadiyah Surabaya, Surabaya - Indonesia \\ Email : levina.yustitianingtyas@fh.um-surabaya.ac.id
}

\begin{abstract}
The state of China or commonly called the State of China has been accused as the cause of an outbreak of corona virus transmission or COVID-19. The loss caused by COVID-19 is very large for all sectors of the country's life sector in the world, so that countries in the world are trying to sue China which is believed to be the country of origin of the virus. The alleged violations against China are the cause of the spread of the COVID-19 virus, causing losses to the economy and community activities, causing dangerous activities such as rampant crime in the community due to the economic crisis, hoarding of food stockpiling and medical equipment as well as several other charges. The difficulty of the resolution mechanism in the international violence because almost all disputes that occur between state are resolved by a mechanism based on mutual agreement of both parties. In this paper, the focus of the problem is to examine the extent to which opportunities can be used by state in the world in suing China for violations of Human Rights as the cause of the outbreak of transmission of COVID-19 and which international court has more authority in handling the case.
\end{abstract}

Keywords- international court; human rights violations; COVID-19

\section{INTRODUCTION}

Stater in the world are currently experiencing a disease outbreak, namely COVID-19, which has succeeded in changing the order of human life, and crippling the country's economy. Almost all countries in the world are trying to get up to rebuild their country life by implementing the "New Normal" era. COVID-19 is a new type of virus that was first discovered in China, this is because the Chinese state was the first to announce that the virus had attacked its citizens, precisely in the city of Wuhan and caused a soaring death rate, not long after the virus spread throughout the world including: Indonesian country. Finally, the world health organization, the World Health Organization, determined this virus outbreak as a global pandemic, this is based on the data obtained that infected around 7,094. [1] COVID-19 is a deadly virus that can be infected with symptoms or without symptoms.

Various policies have been carried out by the state to break the chain of the spread of COVID-19, including locking down foreign nationals who will enter their country and imposing restrictions on their citizens to travel abroad. Activities involving large numbers of people gathering in one place were eliminated and state visits were also replaced by virtual conferences. Such a reality causes the rights of every human being to obtain welfare have been violated and in terms of international relations it has been considered to hinder or hinder the implementation of cooperation between countries, because the cooperation that has been planned is delayed or does not succeed because all countries focus on managing the health of their citizens.

A number of countries have started suing China regarding the spread of COVID-19 because they are considered not transparent. [2] A lawsuit arose in Florida, United States, demanding that the Chinese government provide compensation related to the spread of Covid-19. The same thing happened in several countries including Australia. A newspaper in Germany also calculated the losses suffered by the country. In England there are parties who reveal the same thing. In fact, in the United States the Missouri State Attorney General has filed a lawsuit with the local Court. [3]

The class-action lawsuit, which was supported by thousands of Americans, was handled by a law firm called the Berman Law Group in Miami. The law firm said the lawsuit wanted to demand billions of dollars in compensation for victims of Covid-19 due to China's negligence. They said that the Chinese government had failed to prevent the spread of Covid-19, which now caused problems around the world. "In fact, they have the ability to stop the spread of this virus at an early stage," the law firm said. This law firm is determined to "fight for the 
rights of the people and businessmen in Florida and in the United States who are either sick or have to care for the sick, have financial difficulties, and are forced to experience panic, social restriction and isolation" due to Covid-19. A separate cass-action lawsuit on behalf of the Las Vegas businessman has also been filed. They are demanding billions of dollars in compensation from the Chinese government. The lawsuit in Las Vegas states that the Chinese government should have shared initial information about the virus, but they have instead intimidated doctors, scientists, journalists and legal practitioners while allowing Covid-19 to spread. [3]

Former boss of British intelligence agency MI6 John Sawers revealed information stating that the Chinese government covered up this problem during the period December 2019 and January 2020. Previously, the Bild tabloid in Germany, which is the most widely read in Europe, issued a "bill" of 24 billion euros or around IDR 404 thousand trillion as compensation for tourism revenue during March and April. In addition, Bild also asked for 50 billion euros in compensation of around Rp 841 thousand billion for small and medium enterprises, as well as 149 billion euros if Germany's GDP falls below 4.2 percent this year. Meanwhile, the World Health Organization itself says to date "all available evidence" suggests that the virus originated in animals, most likely from bats. Covid-19 infection in humans was first identified in Wuhan at the end of December. The World Health Organization stated that it does not yet know how the first infection occurred in humans. "At this stage, it is still impossible to determine exactly how humans in China are infected with SARS-CoV-2," the World Health Organization website said. [3]

On the other hand, countries in the world are trying to sue China because the consequences of the virus have caused enormous losses to the life of their country and are accused of violating human rights, namely the right to health (World Declaration on Human Rights 1948, art. 25 verse 1).The alleged violations against China are the cause of the spread of the COVID-19 virus which causes or has a direct impact on the order of life including: losses to the economy and community activities, causing dangerous activities, for example the rampant crime in society due to the economic crisis, hoarding of basic goods and medical equipment as well as several other allegations. There are many problems caused by COVID-19 from various sectors of life in the world, so the writing of this law focuses on the problem of the extent of opportunity that can be used by countries in the world to sue China for human rights violations as the cause of the outbreak of COVID-19 transmission and which international judiciary has more authority in handling such cases.

\section{RESEARCH METHODS}

This legal research is a normative juridical law research. The legal research method analyzes the human rights court mechanism using a statutory approach. The approach in legal research is a process of finding the rule of law, the principles of legal doctrine to answer legal issues that are being raised. This approach starts from legal regulation both from the aspects of international law and national law both vertically and horizontally, to studying legal rules that are parallel or hierarchical. Through a conceptual approach by analyzing cases based on doctrines and views of experts as well as conceptual and theoretical views, this aims to solve the legal problems raised not only with a limited statutory approach. [2]

The field of law that analyzes human rights judiciary as an opportunity that can be used in the resolution of the issue is public international law research, particularly with regard to transnational international crime law, the analysis point used by researchers based on international conventions can be dominant in writing this law. However, human rights research, especially human rights courts, as a rule based system, can also understand the functions and powers of the international tribunal to try the perpetrators of these crimes. This means that multidimensional discourse can be incorporated into this legal research so that it is expected to produce comprehensive legal research. [3] Legal materials obtained from international legal conventions, national legislation, literature reviews based on related themes, as well as from several existing cases.

\section{DISCUSSION}

\section{A. International Dispute Resolution}

Relations between countries in dispute are possible and often unavoidable. In international law, disputes can occur between countries and countries, countries with international organizations or between international organizations and international organizations. the term "international disputes" includes not only disputes between 
countries, but other cases that are within the scope of international regulations, namely certain categories of disputes between the state on the one hand and individuals, bodies corporate bodies as well as non-state bodies on the other. [4]

International disputes are disputes that are not exclusively the internal affairs of a country. International disputes are also not exclusively related to relations between countries, considering that the current international legal subjects have experienced expansion in such a way as to involve many non-state actors. [5] The parties to international disputes can resolve their coup by using peaceful settlement methods or can use violent means. [6] Article 2 of the UN Charter explains that all members of the UN Charter are obliged to resolve international disputes in peaceful ways so as not to endanger international peace and security. Furthermore, related to the peaceful settlement of international disputes is specifically regulated in the UN Charter Chapter VI articles 33 to article 38, in that article it asks the parties to seek a settlement, especially by negotiation, inquiry, mediation, conciliation, arbitration, judicial settlement, using methods existing within the regional framework, or other means they choose and if it deems necessary the Security Council may ask the parties to resolve their disputes in these ways. [6]

The methods for resolving disputes within the framework of international law are as follows:

a. Peacefully: negotiations, mediation, good services (good offices), inquiry

- Legal channels: arbitration, international tribunals

b. Violently: war, non-war; termination of diplomatic relations, retortions, blockades, embargoes, reprisals.

The demands of the countries of the world against China for the spread of COVID-19 has caused enormous losses to the lives of countries in the world and is accused of violating human rights, so if it is based on dispute resolution in international law, it is hoped that the parties can resolve them in a peaceful manner first as mandated by the UN Charter. Before being submitted to an international judicial body, the dispute parties are expected to resolve their deeds using an agreed mechanism.

\section{B. United Nations Human Rights Mechanisms}

The United Nations plays a very important role in promoting and protecting human rights. Protection of human rights is even one of the goals of the United Nations as stated in Article 1 paragraph of the United Nations as follows:

"To achieve international cooperation in resolving international problems in the economic, social, cultural or humanitarian fields and in promoting and promoting respect for human rights and basic freedoms for all without distinction regarding race, sex, language or religion."

Chart of United Nations human rights mechanisms:

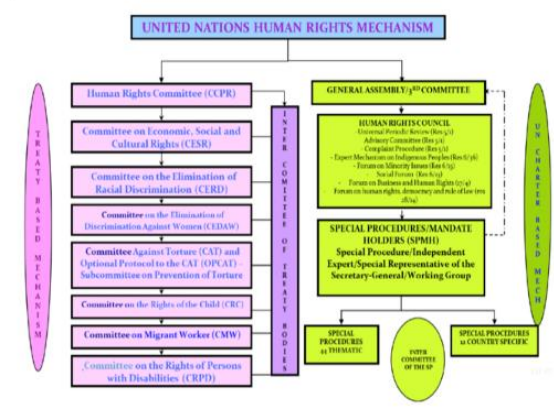

(Source:

https://kemlu.go.id/portal/id/read/87/halaman_list_ other/mekanisme-ham-pbb)

In the event of a violation of international human rights, the United Nations has accommodate the reporting mechanism which is divided into 2 (two) mechanisms as follows:

\section{a. Mechanism based on International Human Rights Treaty (The Treaty Based Mechanisms)}

Treaty Based Mechanisms a complaint mechanisms established based on international human rights treaties or conventions. This international treaty is only valid and binding for countries that have signed and ratified the relevant agreement. Work commissions formed under international agreements are the Human Rights Committee (CCPR), Committee on Economic Social and Cultural Rights (CESR), Committee on the Elimination of Racial Discrimination (CERD), Committee on the Elimination of Discrimination Against Women (CEDAW), Committee Against Torture (CAT) and Optional Protocol to the CAT (OPCAT) Sub committee on Prevention of Torture, Committee on the Right of the Child (CRC), Committee on Migrant Worker (CMW).

In this mechanism, the authority of the working commission is very limited to the rights protected in the convention only, but decisions of human rights working organs or commissions are more binding on the convention participants. The subjects that can 
file complaints or report to the human rights working commission are states, individuals or international organizations as long as they are bound by the agreement.

The requirements for individuals to file complaints using this mechanism are : [7]

1. Derived from a country ratifying the convention and optional protocol

2. Identity must be clear and not use derogatory words and in accordance with existing facts

3. Not being processed through investigative procedures or other international settlement.

4. Exhaustion of local remedies

5. Is the party that suffers the direct impact of the violation being complained of

6. Not retroactive

7. Filing a complaint is within the jurisdiction of the accused country when the violation occurred, but the individual does not have to be a person who is domiciled or residing in that country.

8. Power can be given to people who are related to family or other personal relationships.

Through this mechanism, there are advantages that can be obtained if individuals submit complaints of human rights violations through this mechanism, including being able to get remedies, can be material for changes in policies or legal rules, can be initial evidence of systematic human rights violations and massive if in the country there are serious human rights violations, the results of the investigation carried out by the body concerned will be published, this committee can also take urgent action to request protection for victims so that they do not suffer irreparable suffering, and finally the committee's decision is the final. [7]

\section{b. Mechanisms based on The Charter Based Mechanisms}

This reporting mechanism is a human rights enforcement procedure that is not established by human rights conventions but is based on the UN Charter as mandated in Article 55 and Article 56 of the UN Charter (including the purpose of the UN Charter to promote the resolution of international problems and respect for rights. Human rights throughout the world community, as well as basic freedoms for all) through the Human Rights Council is a United Nations body established under General Assembly Resolution 60/251 dated March 15, 2006 as part of reforms to strengthen. The Council opened its first session on June 15, 2006. At the same time the Commission on Human Rights, a body formed in 1946 by the Economic and Social Council in accordance with Article 8 of the UN Charter, was dissolved. Since the council was in many cases formed on the model of the Commission on Human Rights, a brief historical recapitulation was required. The Human Rights Commission originally consisted of 53 members representing each of their respective countries. The Commission on Human Rights has a broad mandate, and can raise and discuss all kinds of human rights issues.

United Nations human rights protection activities that it includes the Economic and Social Council ("ECOSOC"). The mandates held by the Economic and Social Council ("ECOSOC") include:

"... Promote universal respect and the application of human rights and basic freedoms."

This reporting mechanism can be carried out by all member countries, individuals, community groups or non-governmental organizations if they have direct or indirect knowledge of alleged violations, even though they have not signed and ratified international human rights treaties. The proceedings in this mechanism are at Committee II and Committee III of the General Assembly of the United Nations. The reporting mechanism to the United Nations Human Rights Council can be done through special procedures, working groups and sub-councils on the promotion and protection of human rights.

- Special Procedures

The working duties of special procedures are as a mechanism for finding facts and investigations, conducting country visits, and carrying out factfinding missions by receiving direct reports from the general public. Investigative reports are submitted to the Human Rights Council which will then be used as the basis for political debate and resolution.

- Team work

The working group is open to the participation of all countries and non-governmental organizations. The working group's activities are characterized by debates, discussions, and the making of recommendations for suspected human rights violations, the results of which will be submitted to the Human Rights Council.

- Sub Council on the Promotion and Protection of Human Rights

The sub-commission has the mandate to conduct research, make recommendations, participate in the creation of human rights 
conventions and mechanisms, receive reports, and examine allegations of human rights violations.

\section{Charter Based Mechanism Procedure 1235}

The ECOSOC Council gave authority in the field of human rights to the United Nations Human Rights Council by adopting two procedures, namely through Resolution 1235 (XLII) dated June 6, 1967 and Resolution 1503 (XLVIII) dated May 27, 1970. Through Procedure 1235, Human Rights Council given the power to examine relevant information related to human rights violations received from individuals, non-governmental organizations, and the state as contained in the complaint letter registered by the Secretary General, then conduct an investigation into the pattern of human rights violations. [8] Basically Procedure 1235 is not an individual complaints procedure. In the event that a report is submitted by an individual, the Human Rights Council will direct the information on human rights violations in the general survey of the country concerned. The activities of the Human Rights Council are of an open nature as reported to the ECOSOC council. Only countries that have ratified certain human rights conventions can report or make complaints of human rights violations to the human rights council.

\section{Charter Based Mechanism Procedure $\mathbf{1 5 0 3}$}

Procedure 1503 is structured as an individual complaints procedure. The human rights council is empowered to review confidential individual communications. Communications from victims, and non-governmental organizations that have passed the testing and are received by the Secretary General. The 1503 procedure mechanism allows the commission to handle cases of human rights violations in secret and carried out secretly. According to Philip Alston, as quoted by Pranoto Iskandar in his book International Human Rights Law An Introduction, he explained that the 1503 Procedure is "petition-information" not "petitionredress", due to the absence of compensation to the victim. In other words. [9] Therefore, the most likely sanctions are limited to the emergence of "shaming" shame for the violating state, and no compensation for the victim, because the violation will be discussed in an open discussion. However, not all requests (communication) for complaints are accepted because it must be clear the facts that are alleged, there are consistent human rights violations, the identity of the complainant is clear, if only based on reports from the media it will be difficult to accept.

The weakness of this mechanism is that it consumes a lot of time, is inefficient, confident, so it tends not to be open. Meanwhile, the advantage of this mechanism is that there is no requirement that only states that have ratified certain human rights conventions can file complaints. Simply by submitting evidence that there are human rights violations, it can be submitted to the Human Rights Council according to procedure 1503 .

\section{Chances of a Successful International Court of Justice Complaint to the Human Rights Council}

A number of countries have started suing China regarding the spread of COVID-19 because they are considered not transparent. 40 countries in the world such as the United States, Florida, Australia said that this lawsuit wants to demand billions of dollars in compensation for victims of Covid-19 due to China's negligence. They said that the Chinese Government had failed to prevent the spread of Covid-19, which now caused problems around the world. Meanwhile, the Henry Jackson Society, a think tank in Britain, stated that the Chinese government must take responsibility for the Covid-19 pandemic because of efforts to cover up the problem at an early stage. They argued that the G-7 countries could sue for compensation from China of 3.2 trillion pounds or around Rp. 61 thousand trillion. [10]

Currently, China's position from March 2020 to March 2021 occupies the Consulative Group in the United Nation Human Rights Committee. China is the chairman of 15 special agencies under the auspices of the United Nations. According to the Professor of International Law at the University of Indonesia and the Chancellor of the University of General Achmad Yani, Hikmahanto Juwana, he argues that the main problem in getting compensation suffered is where the lawsuit is filed, what is the basis for the lawsuit and whether the verdict can be executed. If a lawsuit is filed in a court in a country, the Chinese government will easily break it on the grounds that the Chinese government has immunity in the national judiciary. If it is submitted to the International Court of Justice or international arbitration such as the Permanent Court of Arbitration, China must first declare its consent to be the party to be accused. [11]

Although there are judiciary institutions that claim to have the authority to judge, the next issue is what is the basis of the lawsuit. The basis used by 
many is the lack of transparency of the Chinese government at the beginning of the spread of COVID-19. Of course this will not be easy for anyone who sues China because the Chinese government will not give anyone access to get the necessary evidence from the Chinese state.

If the plan of countries in the world trying to obey China is carried out then based on the 1503 procedure there will be no compensation for victims of human rights violations, because not all of these countries have ratified certain human rights conventions. The only sanction that China has received is shame that the Human Rights Council will discuss the violation case in an open discussion.

The COVID-19 pandemic must be a moment of reflection for the international community to work together to find the best solution. International collaborations to deal with climate change, refugees and other global problems have been carried out. It is time for countries to develop solid cooperation to tackle COVID-19. [12]

\section{IV.CONCLUSION}

The peaceful settlement of international disputes is specifically regulated in the UN Charter Chapter VI articles 33 to article 38, in that article it asks the parties to seek a settlement, especially by negotiation, inquiry, mediation, conciliation, arbitration, judicial settlement, using methods existing within the regional framework, or other means they choose and if it deems necessary the Security Council may ask the parties to resolve their disputes in these ways.

In the event of international human rights violations, the United Nations has accommodated a reporting mechanism that is divided into 2 (two) mechanisms, namely: The Treaty Based Mechanism is a complaint mechanism established based on a human rights treaty or convention. International. And the second is The Charter Based Mechanism. This reporting mechanism is a human rights enforcement procedure that is not established by human rights conventions but is based on the UN Charter as mandated in Article 55 and Article 56 of the UN Charter. The reporting mechanism to the United Nations Human Rights Council can be done through special procedures, working groups and sub-councils on the promotion and protection of human rights. China is carried out then based on the 1503 procedure there will be no compensation for victims of human rights violations, because not all of these countries have ratified certain human rights conventions. The only sanction that China has received is shame that the Human Rights Council will discuss the violation case in an open discussion.

\section{REFERENCE}

[1] Wisnu Indaryanto, "Kedaulatan Indonesia Di Antara Virus Corona Versus Asas Resiprositas Dan Asas Manfaat (Tinjauan Yuridis Peraturan Presiden Nomor 21 Tahun 2016 Tentang Bebas Visa Kunjungan," Jurnal Legislasi Indonesia, Volume 17 Nomor 2, Juni 2020.

[2] S. \&. S. Levinkind, SE \&. S. Levinkind, Legal Research How to Find \& Understand The Law (12th Edition), Berkeley: NOLO: Berkeley: NOLO, 2004.

[3] Marzuki P. M., Penelitian Hukum, Jakarta: Kencana Prenada Jakarta, 2005.

[4] Starke J. G., Pengantar Hukum Internasional, 2 Edisi KeSepuluh, Jakarta: Sinar Grafika, 2007.

[5] Sefriani, Hukum Internasional: Suatu Pengantar, Jakarta: Raja Grafindo Persada, 2011.

[6] B. H. I. F. H. UGM, Pengantar Hukum Internasional, Yogyakarta: Fakultas Hukum UGM Press, 2013.

[7] Sefriani, "Peluang Menggunakan Mekanisme HAM PBB Untuk Menyelesaikan Kasus COVID-19," dalam materi presentasi disampaikan pada Seminar Nasional Fakultas Hukum UII, Yogyakarta, 23 April 2020.

[8]

"https://www.hukumonline.com/klinik/detail/ ulasan/lt5943a3f13210d/mekanismepelTerbang-kspecially-ham-di-pbb/," [Online]. Available: www.hukumonline.com. [Diakses 16 Agustus 2020].

[9] Iskandar P., Hukum HAM Internasional Suatu Pengantar, Cianjur: IMR Press, 2012.

[10]

https://www.kompas.com/global/read/2020/04 /22/173549370/sejumlah-negara-mulai-tuntutchina-soal-penyebaran-covid-19?page=all., "https://www.kompas.com," 04 April 2020. [Online]. Available: https://www.kompas.com/global/read/2020/04 /22/173549370/sejumlah-negara-mulai-tuntutchina-soal-penyebaran-covid-19?page=all.. [Diakses 15 Agustus 2020].

[11]

https://www.liputan6.com/global/read/424146 0/bisakah-menggugat-china-ke-pengadilansoal-pandemi-virus-corona-covid-19, "https://www.liputan6.com," April 2020. 
[Online].

Available:

https://www.liputan6.com/global/read/424146

0/bisakah-menggugat-china-ke-pengadilan-

soal-pandemi-virus-corona-covid-19. [Diakses

15 Agustus 2020].

[12] https://theconversation.com/mengapamenuntut-cina-soal-covid-19-adalah-langkahyang-mustahil-dan-berisiko-137601,

"https://theconversation.com," Mei 2020.
[Online].

Available:

https://theconversation.com/mengapa-

menuntut-cina-soal-covid-19-adalah-langkahyang-mustahil-dan-berisiko-137601. [Diakses 15 April 2020].

[13] M. Dedi Supriyadi, Hukum Internasional (dari Konsepsi sampai Aplikasi), Bandung: Pustaka Setia, 2013. 